\title{
Path innovation of rural property mortgage financing in China
}

\author{
Yongchao $\mathrm{Wu}$ \\ School of Economics, Sichuan University, Chengdu, Sichuan, China
}

\begin{abstract}
Rural property mortgage financing, as an important breakthrough to deepen the reform of rural property right system and financial system, is an important approach to increase the farmers' property income. Besides, rural property mortgage financing is of great significance in implementing the rural land usufructuary right and meeting the demand of medium-and-long-term and large-scale operation of the funds used in agricultural production. Under the existing institutional arrangement, the property mortgage financing in the rural areas of our country still is faced with many obstacles, and it is still at the stage of low level development. In this paper closely based on the acceptability and the difficulty in the mortgaged property involving in legal disposal, the author puts forward important methods: clearly define the ownership, unify the urban and rural markets, increase the participation enthusiasm of financing bodies, and improve the supporting policies to promote property mortgage financing in rural area. Finally, the government should give farmers more property rights and revitalize the usufructuary right of agricultural land and its derivative right.
\end{abstract}

Keywords: rural property rights; property rights; mortgage financing; path innovation

\section{THE RAISE OF THE ISSUE}

It is clearly put forward in the Third Plenary Session of the Eighteenth Communist Party of China that the farmers should be given the right of possessing, reaping the benefits, being paid after withdrawing, mortgaging, guaranteeing and inheriting the collective property shares; besides, we should perfect the secondary market which is mainly used for the lease, transferring and mortgage of land. In August 2015, our government formulated and implemented Guiding Opinions of the Implementation of Rural Contracted Land Management Rights and the Rights of Mortgaging Farmers' Housing Property [State issue (2015) no. 45], which claims that we should do well in the pilot work of the management right of rural contracted land (referring to farmland) and the mortgage right of farmers' housing property, and give mortgage financing function to the "two rights", providing a system basis for the large-scale nationwide campaigns of rural property rights mortgage financing. Under the big policy background, the national rural property mortgage financing achieved rapid growth. Besides, each province accelerated registering approval, registration and certificate presenting work, actively carried out rural property mortgage financing pilots, and guided the healthy development of rural property rights circulation market, which greatly activated the potential of rural resources, capital, assets and other kinds of production factors.

In general, our country is still at the stage of exploring and piloting phase of rural property right system reform. Besides, the rural property mortgage financing is still at the low level development stage, therefore, compared with the developed countries possessing systematic theories about farmland property right mortgage, such as land rent theory, property right theory, marketization of farmland changing theory etc., the domestic research started relatively late, and its depth and breadth is not enough, apart from that, there is no necessary theoretical support of domestic research activities. Until January 1st, 2016, if we conduct precise retrieval with the theme of rural property mortgage financing in CNKI database, we can find that there is no more than hundreds of references, and most of the research content focuses on the financing needs and influence factors, laws and regulations, related mechanism construction and financing plan design, etc., besides, the research method is given priority to case study. In practice, on the one hand, the national macro policy encourages people to carry out various forms of rural property mortgage financing, on 
the other hand, the main body of new type agricultural management lacks collateral, and its credit demand is big, which continuously put forward the urgent need that we should circulate the land management right to get mortgage financing. However, essentially, the multilateral forces of promoting rural property rights mortgage financing haven't formed ideal mortgage financing practice yet. In this paper, the author mainly deems that, as collateral, the acceptability and legal disposal of rural property have some problems, thus the path and methods in practice still need further exploration.

\section{NECESSARY CONDITIONS TO CONDUCT RURAL PROPERTY MORTGAGE FINANCING}

Property rights in economics refer ownership comes into existence due to the scarcity of goods, for only scarce items could produce power relationships. Therefore, property rights refer to the right of using resources under the condition that the resources are scarce (Armen Albert Alchian, 1996), which is aimed to make people to form reasonable expectations in exchanging properties with others, thus to realize the internalization of external effect to great extent (Harold Demsetz, 1994). When the property right is not clear, the individual couldn't achieve reasonable expectations in trading with others, some externalities will appear; on the contrary, when the property right relations is specified, the individual will be encouraged to accumulate and protect properties. To realize the function of property right, we should make sure that both the independence of property right and the separable nature of property rights be guaranteed, besides, different property rights of the same assets can be divided into something belonging to different main bodies. It is precisely due to the fact that the property right can be divided and negotiated, and that market main bodies that have different preferences can obtain different assets' properties through market trading, the utilization efficiency of the assets and earnings could be improved.

Rural property rights in this paper also mainly refer to the collective land property rights and other derivative rights from collective land property rights. However, at present, the collective land property rights that possess mortgage financing function mainly refers to the land usufructuary rights, such as the contracted management right of land, the use rights of collective construction land and the famers' right of homestead etc. Therefore, not all the collective land ownership rights and collateral can be used in mortgage financing. The rights that derived from collective land property rights and have finance function also mainly refer to farmers' housing property right, and usufructuary rights of crops and woods, etc. Therefore, the mortgage financing of rural property rights can be defined as the following kind of behavior: on the basis that the rural land rights, registration and certification work are accomplished, the mortgagor, in accordance with the legal procedures, uses the contracted management right of land, farmers' housing property rights, the right of homestead, the use of the collective construction land, the right to use house sites, and crop usufruct etc., as collaterals to mortgage in certain financial institutions to obtain capital financing. As the farmers' property rights, rural property rights has property attribute, in order to realize financing function of property rights mortgage, and there are at least four necessary conditions need to be obeyed:

First, the core issues that clearly stipulated in law about the ownership of the property rights, in the form of law clear ownership, income attribution and purposes are basic premises of rural property mortgage financing. The above not only suggests that the property right ownership is clear, but also suggests that the property rights can be used as collateral to obtain mortgage financing. Besides, if default happens, the obligor could dispose collateral to get compensation funds. Of course, if the rural collective land doesn't realize the separation of ownership, contract right and the right of management, the debtor can't freely through transferring contracted land management rights to obtain loans.

Second, the establishment of an urban and rural market system including rural property market, financial market and the land market is the foundation support of developing rural property rights mortgage financing. Although the rural property is of property attribute, the property will not be actively transferred into property income. Property and property income are just like the source and income flow ${ }^{1}$, thus if we want the property to generate future income stream, we could only make the market assign its power to establish rural property rights circulation trading platform, and finally transfer the source into revenue stream. As the opinion of property rights theory, the most fundamental reason that the land resources can't smoothly realize "three-capitals" transformation lies in the uncertainty and externality of the rural land property rights, if this is not the case, if the rural land property right relationship is defined clearly, ensure that the farmland right could flow freely under the perfect market system at a reasonable cost, and then it is possible to achieve "Pareto Optimality", so there are two prerequisites that farmland resources undergo no degradation and the rural property rights mortgage financing is smoothly carried out.

Third, higher participation enthusiasm of the main bodies of agricultural management and financial institutions is the important condition of carrying out the work of rural property mortgage financing. Rural property right mortgage financing obey the principles

${ }^{1}$ Cheng Xuebin, Chen Mingjin. 2009. Research of property income of urban households. Journal of Statistical Research, (01): 11-19. 
of voluntarism, on the one hand, we should make the agricultural operators become a real insider, participants and beneficiaries, on the other hand, financial institutions could carry on rural property rights mortgage loan business on the basis that there is sustainable financial growth. Therefore, how to arouse the enthusiasm of the two main financing behavior bodies is also crucial for the order of the rural property mortgage financing.

Four, the supporting policies including perfecting property value assessment, risk compensation mechanism and the rural credit system, etc. are an important guarantee to develop rural property mortgage financing. Due to the fact that in the open and free circulation process of rural property rights, the market mechanism failure often occur, especially the imperfect rural financial system and imperfect social security in developing countries need the government to make up for the defects of the market, such as the circulation of rural land is likely to make poor farmers lose their land that they rely on to survive. It is also possible that the delay of the rural credit system construction seriously affects the financing intention of financial institutions.

The four necessary conditions focus on the acceptability and legal disposal of the situation that the rural property is taken as collateral. Mortgage a kind of debt's security form, when the debtor defaults, based on the law, the creditor shall have the right to auction or sell off the mortgaged property to get the priority of getting compensation, thus, to increase the effectiveness of credit debt and reduce the expected credit loss when default happens. If it is explicitly stipulated in the law that some certain property rights shall not be used for mortgaging, especially under the condition that the definition of property is not clear and there is no complete segmentation, the legitimacy of the rural property right as collateral is being questioned. Although financial institutions obtained the auction, transferring, disposing and other rights of collateral of rural property, if most of the rights are confined to circulate in collective economic organizations, the negotiability of the mortgaged property must be greatly discounted. Financial institutions are the main bodies of rural property mortgage financing. The situation that the risk-sharing and reimbursement mechanism is not sound and the participation enthusiasm is not high is a direct manifestation of the fact that it's difficult to dispose the rural property collateral. Based on above analysis, the rural property mortgage financing is more suitable to be carried out in the areas that there is high efficiency of confirmation, registration and issuing of certificates, sound trading market of property rights, open and standard trading behavior, strong desire of transferring farmland, better rural credit environment and sound supporting policies, which is also a research emphasis of path innovation of promoting rural property mortgage financing.

\section{PROMOTE THE INNOVATION PATH OF RURAL PROPERTY MORTGAGE FINANCING}

\subsection{Revise relevant laws and regulations and solve the legitimacy issue of the mortgaged property}

Legality is one of the important characteristics of market economy, and rural property mortgage financing is no exception. Besides, in the process of exchange turnover and collateral and other trading activities, a complete law system is needed in rural property mortgage financing. Judging from our country's "property law", "security law" and "land management law" and other laws and regulations, there are many restrictions of rural property rights in the aspects of its purpose, transferring and treatment. For example, article 37 in "security law" stipulated that "the following properties can't be used as mortgage properties: the land use right of cultivated land, house sites, privately farmed plots of cropland and hilly land and other collectively owned land"; article 184 in "Property law" stipulated that "the land use right of cultivated land, house sites and privately farmed plots of cropland and hilly land and other collectively owned land are not allowed to mortgage". Although [State issue (2015) no. 45] file proposed that the pilot areas could implement pertinent provisions during pilot period, the legal restrictions on rural property mortgage financing are available until the law has been revised.

Therefore, if we want to extend the scale and scope of rural property mortgage financing to the whole country, and to make rural property mortgaged collateral to be acceptable, transferable across the country, we must first solve the problem of the legitimacy of the mortgaged property, especially that, we need to revise related items that are unfavorable to the rural property mortgage financing in "property rights law", "security law", "land management law", "land contract law". From the legislation aspect to broaden policy limit of "conditional mortgage of rural land management right, the right to use house sites, forest right and other rights, finally provide legal safeguard for the rural property mortgage financing and strengthen the property attribute of rural property rights.

\subsection{Clearly define the ownership and solve the division problem of collateral}

The property is divisible under certain historical conditions. After the implementation of household contract responsibility system in our country, we have realized the separation the rural land ownership right and land contractual management right; after the implementation of the conversion of the land, rural land ownership right and land contractual management right also achieved gradual separation. However, the above plan must be accomplished gradually, and the success is not an overnight achievement. In this pro- 
cess, because we can't gather the confirmation of registration method, main bodies and historical data at the same time, the ownership of land would become ambiguous inevitably, which is bad for the implementation of mortgage financing of rural land usufructuary right and its derivative rights.

As a result, the premises of rural property mortgage financing lie in not only the full possession of the property rights, but also the freedom to possess and control properties, which would certain require that the ownership of property right clear and separable.

First, according to the requirements of "separate three powers, implement them stably and flexibility", we should follow the core idea that "return the power to farmers, and make them wield their own right". Besides, we should accelerate the rural property right system reform, implement the collective ownership, stabilize farmers' contract right, and accept flexibility of the right of land management. Second, we should actively develop joint-stock system of farmers, and promote the capitalization of rural collective assets and stock ownership of rural collective land income. Apart from that, we should adequately guarantee farmers' mortgage and security rights about collective assets. Third, we should further implement the registering approval, registration and certificate presenting work, and optimize the household survey, field measurement, public evaluation and other work procedures. Besides, we should strengthen the check of ownership, acreage, use and spatial location, thus to define whom the collective property rights ownership belongs to. Fourth, we should pay more attention to address the problems left over by history, and clear the property rights relationship recorded under the name of village committee or enterprise yet have no legal contract. Furthermore, we should redefine the property right subjects with its peasants and collective organizations as head of the household, thus actually "return power to the people". We should explore how to establish arbitration court of rural property rights, arbitration court of rural finance, land property rights of villages and towns, as well as maintenance assistance center of rural property right. And we should coordinate the property right conflicts.

\subsection{Establish rural property rights market to solve the negotiability problem of mortgage properties}

Rural property right trading market is a property-rights trading platform by law. If there is no sound rural property rights trading market, it is very difficult for rural property mortgage collateral to be transferred and exchanged through market behavior, which directly influence the outcome of whether mortgage bank could obtain mortgage right successfully. Rural property rights circulation market experienced imbalanced development, and the property rights transaction activities of rural collective assets and personal assets exist within a certain range for a long time. However, most of the activities are limited to private trade activities of the two sides in villages and towns, and the existing property right types of grass-roots trade institutions are simple, thus the establishment, operation and supervision of rural property rights exchange institutions remain to be standardized. Besides, the assessment system of property value is not sound, and there are few appraisal institutions, and the professional personnel are insufficient, and the evaluation methods are not appropriate and lack unified management information system. Therefore, the fair value of rural property right market is difficult to be admitted.

Therefore, we need to establish service circulation center of contracted management right of rural land, management and trading center of rural collective assets, and Internet electronic trading platform for rural property collateral where conditions permit. And we will take various forms of cooperation to achieve the above goals, and finally realize the aim of promoting resources sharing, sharing advantages with each other and getting coordinated development. We need to accelerate the standardization of existing rural property rights trading market and its trading process, and bring private transaction of rural property rights into formal system of property rights trading market, and simplify the mortgage registration and management process, thus finally stipulate targeted transaction process and the specifications. We should explore compulsory management system of establishing rural property right as collateral, namely the system in which the executive organization manages the property of executor, and then uses the obtained proceeds to repay creditor's debt. By this way, we could not only avoid the situation that the mortgager loses related rights of collateral directly, but also reduce the losses while the mortgager couldn't realize mortgage right through auction and selling etc. We should making efforts to push forward the construction of rural property rights value evaluation institutions, and introduce competition mechanism into evaluation industry. And we should allow banks, firms and other main bodies to establish rural property evaluation organizations, and put the relevant staff of banks, accounting firms and other financial institutions in the scope of training, thus continuously consolidate and improve the knowledge system of professionals. We should establish information assessment system of rural property mortgage financing, and carry out a dynamic management mechanism.

\subsection{Innovate financial products and services, and improve the enthusiasm of financing conducting bodies}

Rural property mortgage financing in China started late, and mortgage behavior is limited by the law, and the mortgaged property market has not been formed, and rural property mortgage financing belongs to the 
high risk, high cost and low income activities. Therefore, the financial institutions' subjective acceptance degree of rural property mortgage financing is low as a whole. The general scale and quantity of leading enterprises of planting and raising large family, family farms, specialized cooperatives and agricultural industrialization are small across the country, and the effective demand of mortgage financing scale is limited. For the ordinary farmers, because the needed capital quantity of agricultural production and operation is small and the capital obtained is usually from relatives and friends, the accumulation of production and the folk lending. Therefore, the financing demand is usually insufficient.

Innovating rural financial products and service could not only reduce the costs and risk of financial institutions, but also protect the property rights of the main agricultural management bodies. We should actively guide the financial institutions to carry out rural property mortgage business in accordance with the relevant regulations. And we should encourage joint assessment of rural property value. We should build regional rural property mortgage management service network, separate rural property mortgage management institutions from traditional credit institutions, and establish rural property mortgage loan management department to be responsible for the promoting of rural property mortgage financing business. Based on different properties of the collaterals, we should draw differential plan towards the loan interest rate, loan term and repayment form, and provide financial products with more humanization. We should actively develop Internet banking in rural areas and strengthen banking financial institutions' cooperation with Alibaba and other telecommunications companies, thus from the aspects of financing, payment, information and other aspects to promote rural property mortgage financing. We should take professional cooperatives as an important object of promoting rural property rights mortgage financing, and those problems such as the scale of a single farmer is too small, the cost and risk is high, and the farmers are not closely connected with the market. We should actively promote the rural financial and beneficial education, carry out a number of lectures and training, and improve the permeability and awareness of ordinary farmers towards rural property mortgage financing.

\subsection{Improve the risk mitigation and compensation mechanism, and improve the acceptability of mortgaged properties}

Rural property mortgage financing belongs to high risk industry. If there is no corresponding risk sharing and compensation mechanism, as soon as default happens, the financial institutions will face huge losses. The implementation, operation and other procedures of existing risk compensation mechanism also need to be regulated, and the resulting uncertainty seriously affects the loan enthusiasm and the line of credit of financial institutions.

The risk mainly comes from the uncertainty, which is closely related to the asymmetry of the information of mortgage finance act. Therefore, constructing multi-level unified information platform with interconnectivity is one of the effective ways to reduce the rural property mortgage financing risk. We should fully integrate rural property mortgage assessment information system, mortgage registration service information system, the collateral credit database, etc., and establish a management information service platform with a unified standard and multi-stage tandem in each township, county, city, province at different levels and even the whole country, We should establish rural property rights circulation guarantee and risk sharing mechanism to support agricultural guarantee company to thrive. Besides, we should use rural land property rights trading platform to provide guarantee service to agricultural enterprise, professional cooperatives and farmers that deal with rural property mortgage financing. We should actively promote "bank-insurance cooperation" and "bank-government cooperation", and establish mortgage financing risk fund of rural property, which is targeted to buy the debts that the rural property mortgage finance becomes due and can't be repaid. Give full play to the risk the rural mortgage financing sharing role of agricultural insurance in rural property mortgage financing. We should promote the establishment of rural credit system, and strengthen the information management of rural property mortgage registration, thus gradually establish a unified rural property mortgage registration service system and credit database and files of rural property right mortgagor.

\section{ACKNOWLEDGEMENT}

This paper is funded by the Present Situation, Problems and Countermeasures of Rural Property Mortgage Financing (SC13JR02)

\section{REFERENCES}

[1] Yin Yunsong. 1995. On the farmland financial system which is characterized by the mortgage of the right to use agricultural land. China's Rural Economy, (6):36-40.

[2] Han Changfu. 2014. Several issues about deepening the reform in rural area. Journal of Rural Work, (22): 7-12.

[3] Deng Gang. 2010. The problems and prospects of the reform of property mortgage and financing system in rural area in our country--Based on the analysis of relevant policies in Chengdu. Agricultural Economy, (11): $67-72+111$.

[4] Wan Guangjun, Yang Suiquan. 2011. Research of mortgaged properties of mortgage financing in rural area-Enlightenment from Chengdu's experience. Journal of the Reform of Economic System, (02): 92-97. 
[5] Xiao Shishun, Gao Feng. 2010. Research of rural household loan model of rural financial institutions--Based on the perspective of rural land property rights. Journal of Agricultural Economy, (4): 14-18+110.

[6] Zeng Qingfen. 2010. Empirical research of rural residents' intention of property financing under the back- ground of property rights reform: Take Chengdu "Test Area" as an example. Journal of Central University of Finance and Economics, (11): 63-68.

[7] Gao Shengping, Liu Ping. 2009. The credit collateral in rural financial system: Plights and outlets. Journal of Financial Research, (02): 64-72. 